DOI: 10.46340/eppd.2020.7.3.11

\author{
Yehor Savych \\ ORCID ID: https://orcid.org/0000-0003-1216-8583 \\ Institute of Legislation of the Verkhovna Rada of Ukraine
}

HUMAN (CITIZEN'S) APPEAL

\title{
AS A CONSTITUTIONAL AND LEGAL CATEGORY: DISCUSSION ISSUES
}

\author{
Єгор Савич \\ Інститут законодавства Верховної Ради України

\section{ЗВЕРНЕННЯ ЛЮДИНИ (ГРОМАДЯНИНА) ЯК КОНСТИТУЦЙНО-ПРАВОВА КАТЕГОРІЯ: ДИСКУСІЙНІ ПИТАННЯ}

The article aims to reveal the essence of the concept of "appeal" and analyze it as a constitutional and legal category, which will include clarification of its legal nature, essence, and content, as well as the characteristics of the types of appeals and their features. This will not only improve the understanding of the functional purpose of the constitutional human right to appeal but also serve as a theoretical and methodological basis for improving the legal guarantees for the implementation of this right. It has been established that this concept is not defined by national legislation. The author has suggested his own definition of the "human (citizen's) appeal" and proves that this concept is a guideline of the modern substantive and functional content of the human right to appeal. The right to appeal is one of those constitutional human rights and freedoms in Ukraine, which serve as a "bridge" to establish an effective mechanism of communication between the individual, society, and the state and ensure the construction of civil society.

Keywords: statements, appeals of a person (citizen), constitutional human right to appeal, proposals, complaints.

Постановка проблеми. Право на звернення є одним із тих конституційних прав і свобод людини в України, які, так би мовити, слугують «містком» для налагодження ефективного механізму комунікації особи, суспільства і держави та забезпечують побудову громадянського суспільства.

Компаративний аналіз статті 40 Конституції України та норм Закону України «Про звернення громадян» від 2 жовтня 1996 року засвідчує відсутність повного змістовного збігу їх положень. Так, конституційно-правова норма гарантує кожному право направляти індивідуальні чи колективні письмові звернення або особисто звертатися лише до органів державної влади, органів місцевого самоврядування та посадових і службових осіб цих органів, що зобов'язані розглянути звернення і дати обгрунтовану відповідь у встановлений законом строк. Натомість чинні положення базового Закону суттєво розширюють перелік суб'єктів, до яких може бути адресовано звернення, надаючи право подання звернень до підприємств, установ, організацій незалежно від форм власності, об’єднань громадян, засобів масової інформації.

Крім того, конституційні та законодавчі положення (частина третя статті 1 Закону України «Про звернення громадян») декларують право на звернення як конституційне право людини. Утім, назва Закону обмежує коло суб’єктів, які можуть направляти звернення, лише громадянами України.

Проте, найсуттєвішим недоліком чинного Закону України «Про звернення громадян», на наш погляд, $є$ відсутність у його приписах визначення поняття «звернення громадян». У нормі частини першої статті 3 цього Закону сказано лише, що «під зверненнями громадян слід розуміти викладені в письмовій або усній формі пропозиції (зауваження), заяви (клопотання) і скарги» ${ }^{1}$

\footnotetext{
1 Закон про звернення громадян, 1996 (Верховна Рада України). Офіиіійний сайт Верховної Ради Украӥни $<$ https://zakon.rada.gov.ua/laws/show/393/96-\%D0\%B2\%D1\%80>. (2020, травень, 14).
} 
Стан дослідження. Теоретичні аспекти інституту звернень громадян досить лімітовано розглядались у працях вітчизняних конституціоналістів. Здебільшого аналіз видів звернень та їх характеристика ставали предметом наукового інтересу фахівців 3 адміністративного права та державного управління. Зокрема, цих аспектів торкались у своїх роботах такі вчені, як Н. Каменська, С. Кандзюба, К. Кісілевич, Л. Кисіль, О. Костюкевич, О. Кравцов, Д. Лученко, М. Поворознюк, В. Соболь, В. Цимбалюк, О. Чуб, В. Шапіро та інші. Недостатність теоретичної розробки даної наукової тематики саме у науці конституційного права породжує обмежене розуміння сутності та функціонального призначення права людини на звернення та обумовлює потребу більш детального та виваженого висвітлення й аналізу його базових понять.

Метою статті $\epsilon$ аналіз поняття «звернення» як конституційно-правової категорії, який включатиме з'ясування його юридичної природи, сутності та змістовного наповнення, а також характеристику видів звернень та їх особливостей. Це не лише покращить істинність розуміння функціонального призначення конституційного права людини на звернення, а й слугуватиме теоретико-методологічною основою для удосконалення правових гарантій реалізації означеного права.

Виклад основного матеріалу. У науковій літератури виділено низку особливостей щодо характеристики змістовного наповнення, видової класифікації звернень громадян, дискусію 3 приводу яких розпочато ще радянськими дослідниками.

Так, В. Ремньов, аналізуючи такий вид звернення як пропозиції, відзначав, що його мета полягає в тому, щоб звернути увагу на недосконалість регулювання тієї чи іншої галузі суспільних відносин ${ }^{1}$. В. Мальков, у свою чергу, зазначав, що мета пропозиції полягає саме в рекомендаціях, що спрямовані на поліпшення та вдосконалення роботи органів державної влади та місцевого самоврядування, а не фіксування недоліків без вказівки на можливі шляхи та засоби їх усунення ${ }^{2}$, а В. Новосьолов відзначав, що пропозиція є самостійним видом звернення, в якому зачіпляються питання особистого, державного чи суспільного характеру. При цьому автор особливу увагу звернув на те, що пропозиції містять елементи особистого ставлення особи до порушуваних питань, що відображають іiі зацікавленість удосягненні певної мети державного або суспільного характеру ${ }^{3}$.

Сучасна українська дослідниця В. Шапіро, у свою чергу, аналізуючи види звернень громадян виділила характерні для них ознаки. Так, пропозиції (зауваження) мають особливий рекомендаційний характер, вони є висловленням думки індивіда щодо врегулювання суспільних відносин та умов життя, вдосконалення правової основи державного та громадського життя, соціально-культурної та інших сфер діяльності держави і суспільства. Пропозиції спрямовані на вдосконалення певних сфер суспільного життя виникають як такі на основі наявної практики, в тому числі і негативної. Це пояснюється тим, що інформація, яка міститься у такому роді звернення, може нести у собі й елементи критики. Заява (клопотання) є другим видом звернень. Вона $\epsilon$, по-перше, проханням з боку громадянина про сприяння реалізації закріплених Конституцією та чинним законодавством України його прав та інтересів. По-друге, заява $є$ повідомленням громадянина про порушення чинного законодавства або недоліки в діяльності підприємств, установ, організацій незалежно від форм власності, депутатів різних рівнів, посадових осіб. I, по-трете, в змісті заяви можуть міститись думки громадянина щодо поліпшення діяльності суб'єкта, до якого адресоване звернення. Останнім, третім видом звернення є скарги, метою якого є поновлення порушених прав та захист законних інтересів громадянина, що порушені діями (бездіяльністю), незаконними рішеннями державних органів, органів місцевого самоврядування, їх посадовими особами, чи інших суб'єктів звернення. Характерними властивостями скарги $є$ обов'язкова наявність факту порушення прав, свобод і законних інтересів громадянина, специфічна мета, що ії характеризує - захист або поновлення порушеного права, досягнення певного результату, що має на меті відновлення порушеного права ${ }^{4}$.

\footnotetext{
${ }^{1}$ Ремнев, В. И. (1964). Право жалобы в СРСР. Москва: Юридическая литература, 23.

${ }^{2}$ Мальков, В. В. (1967). Советское законодательство о жалобах и заявлених. Москва: МГУ, 16.

${ }^{3}$ Новоселов, В. И. (1976). Правовое положение граждан в советском государственном управлении. Саратов: СГУ, 133.

${ }^{4}$ Шапіро, В. С. (2012). Особливості правового регулювання права громадянина України на звернення. Форум права, 4, 1034-1043.<http://nbuv.gov.ua/UJRN/FP_index.htm_2012_4_173>. (2020, травень, 14). [in Ukrainian].
} 
Вітчизняна дослідниця Л. Кисіль, аналізуючи види звернень громадян у статті 3 Закону України «Про звернення громадян», звернула увагу на те, що пропозиції та зауваження становлять один термін, а заяви об'єднані з клопотаннями, хоча визначені вони окремо. На ï думку, така класифікація не дає відповіді на питання про їх критерії та не враховує появи нових різновидів звернень громадян у вигляді інформаційного запиту та запиту щодо роз'яснення законодавства, електронної петиції. Адже пропозиція - звернення із суспільно значущих питань, а заяви і скарги 3 питань особистого характеру. Крім того, зміст усталених категорій звернень громадян $\epsilon$ надзвичайно різноманітним. Це поради, рекомендації, зауваження, міркування, побажання пропозиції. Це і прохання, повідомлення про порушення та висловлення думки про їх усунення заяви, а також прохання - клопотання. Це і вимога про поновлення прав та захист інтересів - скарга. На практиці здебільшого звернення громадян викладаються таким чином, що досить часто змістовно містять ознаки і скарги, і пропозиції, і заяви, і зауваження. Тому, питання класифікації звернень громадян має не лише теоретичне, а й практичне значення, оскільки дає змогу пізнати їх різноманіття, більш чітко визначити вимоги до різних категорій звернень, уточнити права та обов’язки учасників відповідних правовідносин та порядок їх реалізації ${ }^{1}$

У науковій періодиці питання класифікації звернень громадян $\epsilon$ й досі актуальним. Наприклад, О. Чуб за критерієм характеру питання, з яким громадяни звертаються до органів публічної адміністрації, пропонує вирізняти звернення публічного та приватного характеру ${ }^{2}$, а Г. Котляревська - пропозиції, зауваження і повідомлення як звернення публічного характеру та клопотання і скарги як звернення приватного характеруз.

Л. Кисіль, у свою чергу, вважає, що за змістом звернень громадян до органів публічної адміністрації доцільно вирізняти: 1) пропозиції- звернення, що містить поради, рекомендації, побажання щодо підвищення ефективності організації та діяльності органів публічної адміністрації, нормативно-правового регулювання у сфері публічного управління; 2) зауваження - звернення, що містять критичну оцінку діяльності органів публічної адміністрації на їх посадових осіб, вказівки на недоліки у правовому регулюванні відносин упевній сфері публічного управління; 3) повідомлення - звернення 3 метою інформування органів публічної адміністрації про необхідність вжиття заходів профілактики або усунення порушень законодавства, що зачіпають законні інтереси невизначеного кола осіб; 4) заяви - звернення до органів публічної адміністрації 3 метою реалізації належних громадянам прав, свобод і законних інтересів, виконання покладених законом обов'язків; 5) скарги - звернення до органів публічної адміністрації з вимогою про захист, поновлення суб'єктивних прав, охоронюваних законом свобод, законних інтересів скаржника, а в окремих випадках - i третіх осіб. При цьому, пропозиції, зауваження і повідомлення $\epsilon$ зверненнями публічного характеру, а заяви і скарги - приватного характеру ${ }^{4}$.

Аналізуючи представлену авторську класифікацію, на нашу думку, слід наголосити на такому. По-перше, певні сумніви викликає доцільність виділення такого виду звернень громадян як «повідомлення», тим паче, з огляду на тлумачення цього слова в українській мові як «письмової чи усної інформації» ${ }^{5}$, тобто, інформація, що стосується широкого кола питань. Окрім того, дослідниця уникає відокремлення такого виду звернень громадян як «клопотання». Натомість штучно розмежовує терміни «пропозиція» та «зауваження», хоча наведені поняття на практиці, як правило, є змістовним та логічним продовженням одне одного, оскільки поради, рекомендації, побажання щодо підвищення ефективності діяльності органів державної влади і місцевого самоврядування, депутатів усіх рівнів, посадових осіб, безпосередньо пов'язані з висловленням певної критичної оцінки з приводу їх діяльності.

\footnotetext{
${ }^{1}$ Кисіль, Л. Є. (2017). Відносини, що виникають за зверненнями громадян до органів публічної адміністрації: деякі аспекти адміністративно-правового регулювання. Часопис Київського університету права, 3, 109-113. $<$ http://nbuv.gov.ua/UJRN/Chkup_2017_3_24>. (2020, травень, 14).

2 Чуб, О. О. (2005). Конститучійне право громадян на участь в управлінні державними справами. Харків: Одісей, 126.

${ }^{3}$ Котляревська, Г. М. (2010). Методичні питання класифікації звернень громадян до органів влади. Юридична Україна, 5, 37.

${ }^{4}$ Кисіль, Л. С. (2017). Відносини, що виникають за зверненнями громадян до органів публічної адміністрації: деякі аспекти адміністративно-правового регулювання. Часопис Київського університету права, 3, 109-113. $<$ http://nbuv.gov.ua/UJRN/Chkup_2017_3_24>. (2020, травень, 14).

${ }_{5}^{5}$ Бусел, В. Т. (ред.) (2004). Великий тлумачний словник сучасної украйнської мови. Київ-Ірпінь: Перун, 811.
} 
О. Костюкевич у своїх наукових працях викладає дещо удосконалене, на його думку, визначення терміну «пропозиція (зауваження) - це звернення громадян, у якому висловлюється порада, рекомендація щодо діяльності органів державної влади і місцевого самоврядування, депутатів усіх рівнів, посадових осіб, звертається увага на існуючі недоліки, що не пов'язані 3 порушенням законодавства, висловлюються думки щодо врегулювання суспільних відносин та умов життя громадян, удосконалення правової основи державного і громадського життя, соціальнокультурної та інших сфер діяльності держави та суспільства» ${ }^{1}$.

Вітчизняний фахівець з адміністративного права Н. Каменська також пропонує авторську класифікацію звернень громадян до органів публічної адміністрації за змістом та, власне, формулює їх визначення. Так, за змістом (призначенням) звернень - пропозиції, заяви, скарги, інформаційні запити, запити щодо роз'яснення законодавства. При цьому, вона розуміс під дефініцією «пропозиції» - «звернення фізичної особи (фізичних осіб), юридичної особи (юридичних осіб) до органу (органів) виконавчої влади, місцевого самоврядування, що спрямоване рекомендувати заходи удосконалення, правового, організаційного регулювання суспільних відносин усфері державного управління, підвищення ефективності функціонування окремих суб' єктів владних повноважень»; під «заявою до публічної адміністрації» - «звернення фізичної особи (фізичних осіб), юридичної особи (юридичних осіб) до органу (органів) виконавчої влади, місцевого самоврядування щодо реалізації суб'єктивних прав, охоронюваних законом свобод, законних інтересів заявника, виконання покладених законом обов'язків або повідомлення про необхідність вжиття заходів профілактики або усунення порушень законодавства, що зачіпають інтереси невизначеного кола осіб», а під «скаргою до публічної адміністрації» - «звернення фізичної особи (фізичних осіб), юридичної особи (юридичних осіб) до органу (органів) виконавчої влади, місцевого самоврядування з вимогою про захист, поновлення суб'єктивних прав, охоронюваних законом свобод, законних інтересів скаржника, а в окремих випадках - і третіх осіб»².

Такі дослідники як О. Костюкевич, К. Кісілевич, В. Цимбалюк також схиляються до думки про доцільність виділення інформаційного запиту як окремого виду звернень громадян. Наприклад, О. Костюкевич формулює його визначення як «звернення з проханням надати документовані або публічно оголошені відомості, необхідні для реалізації відповідних прав, свобод та законних інтересів» ${ }^{3}$.

Аналізуючи такі підходи до класифікації звернень громадян, зазначимо, що вони здійснені, як правило, у рамках науки адміністративного права та звужені за суб'єктним складом лише зверненнями громадян до органів публічної адміністрації (виконавчої влади). Окрім того, пропозиції включити у цей перелік інформаційні запити та запити щодо роз'яснення законодавства, на наш погляд, є необгрунтованими.

Насамперед варто відзначити, що право на звернення та право на доступ до публічної інформації тісно пов’язані між собою. Разом із тим, їх розмежування визначено на конституційному та законодавчому рівнях. Так, частиною другою статті 2 Закону України «Про доступ до публічної інформації» передбачено, що «цей Закон не поширюється на відносини ... у сфері звернень громадян, які регулюються спеціальним законом», а частина перша статті 19 цього ж Закону надає дефініцію «запит на інформацію» як «прохання особи до розпорядника інформації надати публічну інформацію, що знаходиться у його володінні».

Отже, відмінність між інформаційним запитом та зверненням громадян встановлена як за змістовними, так і за формальним ознаками. Так, за змістом звернення стосуються відстоювання прав і законних інтересів громадянина та пропозицій щодо діяльності органів державної влади, органів місцевого самоврядування, їх посадових осіб, підприємств, установ, організацій незалежно від форм власності, об’єднань громадян, викриття недоліків (зауваження) в їх роботі, а в запитах

\footnotetext{
${ }^{1}$ Костюкевич, О. К. (2011). Адміністративно-правове регулювання реалізації права громадян на звернення: автореферат дисертаиї̈ на здобуття наукового ступеня кандидата юридичних наук. Київ: Міжрегіональна академія управління персоналом, 14.

${ }^{2}$ Каменська, Н. (2014). Класифікація звернень до органів публічної адміністрації за змістом: дискусійні питання. Юридична Україна, 9, 10-13. <http://nbuv.gov.ua/UJRN/urykr_2014_9_4>. (2020, травень, 14).

${ }^{3}$ Костюкевич, О. К. (2011). Адміністративно-правове регулювання реалізації права громадян на звернення: автореферат дисертаиії на здобуття наукового ступеня кандидата юридичних наук. Київ: Міжрегіональна академія управління персоналом.
} 
на інформацію мова йде про надання публічної інформації, якою володіє або повинен володіти ії розпорядник. За формою між зверненням і запитом також $є$ відмінності, а саме: порядок оформлення, процедура реєстрації та обліку та порядок отримання інформації ${ }^{1}, 2$.

3 наведеного, очевидно, що Закон України «Про доступ до публічної інформації» надає право доступу до вже існуючої інформації (документів) і не вимагає створення у відповідь на запит нової інформації (зокрема, шляхом проведення аналітичної роботи). Саме тому, інші вимоги або прохання (визнати чи підтвердити юридичний статус, поновити порушене право, притягти порушника до відповідальності тощо) повинні розглядатися в межах Закону України «Про звернення громадян», бо внаслідок їх розгляду при наданні відповіді на звернення може створюватися нова інформація.

I все ж, незважаючи на те, що право звертатися з інформаційним запитом $є$ складовою конституційного права людини на інформацію, а право людини на звернення утворює окреме самостійне конституційне право, та те, що їх ні в якому разі не варто ототожнювати, між ними спостерігається певна функціональна спорідненість. Обидва ці права не просто гарантують індивіду можливість звертатися до органів публічної влади для задоволення своїх інтересів, а виступають інструментом суспільного контролю, забезпечують розвиток комунікативної взаємодії між державою та громадянським суспільством.

При характеристиці регламентованих у Законі України «Про звернення громадян» видів звернень, українська дослідниця Н. Каменська звернула увагу на те, що найбільш численним видом звернень до публічної адміністрації є заяви. Така ситуація, на ії погляд, обумовлюється метою їх ініціювання реалізація прав, охоронюваних законом свобод та законних інтересів заявника; привертання уваги адресата до державних чи суспільних проблем, що безпосередньо не стосуються ініціатора звернення ${ }^{3}$, а на думку К. Кісілевича та В. Цимбалюка, найбільш поширеним видом звернень на сьогоднішній день $\epsilon$ скарги громадян. Можливість захисту прав громадян за допомогою подання скарги, встановлена значною кількістю актів, у відповідності з якими широкому колу відповідних посадових осіб ставиться обов'язок розглядати адміністративні скарги. Адресатами скарги можуть бути: Президент України; Уповноважений Верхової Ради з прав людини; органи виконавчої влади (в тому числі, вищі) і їх посадові особи та інші уповноважені розглядати скарги суб'єктич'.

Окремі дослідники зазначають, що вітчизняне законодавство про звернення громадян регулює різні за своєю суттю правові явища - «пропозиції», «заяви» та «скарги». Тобто в той час, коли заява є звичайним інструментом щодо врегулювання певної неконфліктної реалізації права громадянина, скарга $\epsilon$ інструментом захисту його законних прав $\mathrm{i}$, таким чином, функціонально знаходиться на одному рівні із судовим позовом. Ці структурні відмінності між різними врегульованими в Законі України «Про звернення громадян» формами ініціатив, 3 якими громадяни звертаються до органів управління, не враховуються цим Законом у повному обсязі. 3 огляду на зазначене, виникають сумніви щодо доцільності врегулювання в одному законі процедури подання пропозицій, заяв та скарг5 .

Дійсно, ми погоджуємось з думкою тих дослідників, які відзначають відмінність юридичної природи таких правових понять як «заяви» та «скарги». Вони цілком аргументовано підкреслюють, що останні, на відміну від пропозицій та заяв, як прохань про задоволення суб'єктивних прав і законних інтересів, які слугують сигналом про порушення нормативної діяльності державного апарату, про зловживання, незаконні дії, які зачіпляють права та інтереси заявника, мають відмінну юридичну природу - правоохоронну, оскільки направляються до органів публічної адміністрації

\footnotetext{
${ }^{1}$ Міністерство юстиції України (2020). Право на доступ до інформації як елемент правового статусу особи $<$ https://minjust.gov.ua/m/str_40016>. (2020, травень, 14).

2 Закон про доступ до публічної інформаиії, 2011 (Верховна Рада України). Офіиійний сайт Верховної Ради Украӥни <https://zakon.rada.gov.ua/laws/show/2939-17>. (2020, травень, 14).

${ }^{3}$ Каменська, Н. (2014). Класифікація звернень до органів публічної адміністрації за змістом: дискусійні питання. Юридична Украӥна, 9, 10-13.<http://nbuv.gov.ua/UJRN/urykr_2014_9_4>. (2020, травень, 14). ${ }^{4}$ Цимбалюк, В. С., Кісілевич, К. О. (2017). Звернення громадян як важлива складова захисту прав і свобод людини і громадянина в Україні. Молодий вчений, 5.1 (45.1), 149-154.

$<$ http://molodyvcheny.in.ua/files/journal/2017/5.1/37.pdf >. (2020, травень, 14).

${ }^{5}$ Кравцов, М. О. (2020). Звернення громадян як механізм публічного діалогу органів державної влади та суспільства. Державно-управлінські студї <http://studio.ipk.edu.ua/wp-content/uploads/2020/04/ Kravtsov_stattia-DUS.pdf>. (2020, травень, 14).
} 
з метою поновлення протиправно обмеженого чи порушеного права, законного інтересу скаржника, а в окремих випадках - третіх осіб ${ }^{1}$.

Вважаємо цілком слушною думку про те, що за допомогою скарги автор, у першу чергу, намагається захистити суб'єктивні права чи законні інтереси тощо, а вже потім опосередковано поінформувати про це адресата.

Адміністративну скаргу як процесуальний засіб захисту прав громадянина в публічноправових відносинах, вітчизняний дослідник М. Поворознюк характеризує як звернення суб'єкта публічно-правових відносин (суб'єкта права на звернення), що адресоване суб'єкту владних повноважень, до повноважень якого належить вирішення публічно-правового спору (суб'єкта вирішення адміністративної справи), з вимогою захисту та поновлення суб'єктивних прав, законних інтересів та свобод громадянина, які порушені неправомірним рішенням, дією чи бездіяльністю суб'єкта владних повноважень при здійсненні ним публічно-владних управлінських функцій на основі законодавства².

Правовою основою скарги як виду звернення громадян та судового позову є Конституція України. Саме вона у статтях 40 та 55 гарантує право людини на альтернативні способи захисту та поновлення порушених прав, свобод та законних інтересів, як в порядку адміністративного оскарження неправомірних рішень, дій чи бездіяльності суб'єктів владних повноважень, так і в судовому порядку шляхом подання адміністративного позову.

Щодо питання функціонального призначення скарги як виду звернення громадян та судового позову в адміністративному порядку, то вони мають як ряд спільних, так і низку відмінних ознак. Серед ознак, які є спільними і для скарги, і для адміністративного позову, можна виділити такі: 1) це процесуальна форма вирішення адміністративно-правового спору; 2) подаються у зв'язку із захистом прав і законних інтересів скаржника (позивача); 3) становлять вимогу про захист прав, свобод, законних інтересів заявника, подану до суб'єкта, компетентного розглядати відповідні адміністративно-правові спори.

Говорячи про відмінності, що вирізняють скаргу як специфічний засіб оскарження i процесуальну форму захисту прав, слід зазначити, що скарга $\epsilon$ засобом позасудового (адміністративного) оскарження, тоді як позов - засіб оскарження рішень, дій або бездіяльності суб'єкта владних повноважень до суду. У цьому сенсі подання і розгляд скарги має низку особливостей порівняно 3 провадженням у судовій адміністративній справі: 1) скарга подається безоплатно (стаття 21 Закону України «Про звернення громадян»). Натомість до адміністративного позову мають бути додані докази сплати судового збору (частина третя статті $161 \mathrm{KACУ);} \mathrm{2)} \mathrm{розгляд}$ скарги зазвичай відбувається у більш спрощеному порядку порівняно із розглядом позовної заяви, оскільки після адміністративного оскарження (чи навіть замість нього) фізична чи юридична особа може використати механізм судового оскарження ${ }^{3}, 4,5$.

Анахронізмом називає вітчизняний науковець Д. Лученко спроби окремих дослідників обгрунтувати позицію, за якою скарга в адміністративно-правових спорах асоціюється з проханням про милість, навіть у тому разі, коли посадова особа чи орган управління порушують права або законні інтереси приватних осіб: до «влади» не можна подати вимогу, на неї можна лише поскаржитись іншій владі. Натомість адміністративний спір зумовлює вимогу про захист i відновлення права відповідно до норм законуㅎ․

\footnotetext{
${ }^{1}$ Каменська, Н. (2014). Класифікація звернень до органів публічної адміністрації за змістом: дискусійні питання. Юридична Україна, 9, 13.<http://nbuv.gov.ua/UJRN/urykr_2014_9_4>. (2020, травень, 14).

2 Поворозню, M. I. (2017). Адміністративний позов у системі засобів захисту прав громадянина у сфері публічно-правових відносин. Часопис Київського університету права, 3, 137-145.

$<$ http://nbuv.gov.ua/UJRN/Chkup_2017_3_31>.(2020, травень, 14).

${ }^{3}$ Кодекс адміністративного судочинства України, 2005 (Верховна Рада України). Офіційний сайт Верховної Ради України <https://zakon.rada.gov.ua/laws/show/2747-15>. (2020, травень, 14).

${ }^{4}$ Конституичія Украӥни, 1996 (Верховна Рада України). Офіиійний сайт Верховної Ради Украӥни

$<$ https://zakon.rada.gov.ua/laws/show/254\%D0\%BA/96-\%D0\%B2\%D1\%80>. (2020, травень, 14).

5 Закон про звернення громадян, 1996 (Верховна Рада України). Офіційний сайт Верховної Ради Украӥни $<$ https://zakon.rada.gov.ua/laws/show/393/96-\%D0\%B2\%D1\%80>. (2020, травень, 14).

6 Лученко, Д. В. (2014). Скарга як процесуальна форма правозахисту в адміністративно-правових відносинах. Вісник Національного університету «Юридична академія України імені Ярослава Мудрого». Економічна теорія та право, 1, 285-294. <http://nbuv.gov.ua/UJRN/Vnyua_etp_2014_1_32>. (2020, травень, 14).
} 
Очевидно, що подібні вислови навіть не потребують коментарів.

Український фахівець з адміністративного права В. Авер'янов вважає, що механізм адміністративної скарги $є$ доповненням судової форми захисту та зазначає при цьому, що кожен громадянин має альтернативу та самостійно обирає шлях захисту свого порушеного суб'єктивного права ${ }^{1}$, а О. Циганов, у свою чергу, зазначив, що адміністративне оскарження є не обмеженням права на правовий захист, а, навпаки, додатковою гарантією захисту прав та законних інтересів приватної особи ${ }^{2}$.

У цьому сенсі ми не можемо погодитись 3 тим, що скаргу як вид звернень громадян варто розглядати лише як допоміжний механізм захисту порушених прав, свобод та законних інтересів порівняно з судовим захистом. На нашу думку, надання громадянам права за своєю ініціативою вибрати інстанцію для розгляду своєї скарги при тому, що за будь-яких умов за ним залишається право звернення до суду, якщо він буде незадоволений результатами розгляду скарги, поданої в адміністративному порядку, $\epsilon$ ознакою цивілізаційного розвитку України та дозволяє стверджувати про існування рівнозначних альтернативних правових механізмів захисту прав, свобод та законних інтересів людини і громадянина в управлінській сфері. При цьому, на перший план виходять не судові механізми захисту та поновлення порушених прав та законних інтересів особи, а комунікативна взаємодія особи, суспільства та державних органів.

Загалом сучасне розуміння інституту звернень громадян як симбіозу інтересів особи, суспільства та держави варто розглядати не в сенсі звуження чи протиставлення пріоритетності одна одній його функцій, а у більш широкому форматі через визнання рівномірного співвідношення особистих, суспільних та державних інтересів, які характеризуються взаємодією та взаємозалежністю, як закономірне продовження української національної правової традиції визнання діалогових форм участі громадян в державному управлінні та суспільному житті як базових.

На комплексний характер функціонального призначення інституту звернень громадян звернули увагу й окремі вітчизняні дослідники. Це дало їм змогу охарактеризувати його як своєрідну форму громадського контролю, за допомогою якого виражаються погляди, пропозиції чи невдоволення громадян тими чи іншими діями органів державної влади, які повинні бути розглянуті та 3 приводу яких необхідно прийняти рішення. Крім того, право на звернення $є$ важливим конституційно-правовим засобом захисту та однією з гарантій дотримання прав і свобод громадян. Адже, звернення громадян $є$ однією з форм участі населення в державному управлінні, у вирішенні державних і суспільних справ, можливістю активного впливу громадянина на діяльність органів державної влади та місцевого самоврядування. Звернення громадян $є$ також ефективним способом відновлення порушеного права громадянина через подання до органів державної влади скарг, заяв і клопотань ${ }^{3}$.

Такі вітчизняні науковці як С. Кандзюба, О. Кравцов, В. Соболь одностайні у висновках про функціональне призначення інституту звернень громадян до органів влади: як одного із засобів захисту прав громадян, що дозволяє запобігати порушенням, зловживанням, негативним впливам, своєчасно усувати дестабілізуючі наслідки (правозахисна функція); як цінного джерела відомостей для органів державної влади та органів місцевого самоврядування про проблеми громадян (інформаційна); як ефективного засобу комунікації між державою та громадянами (комунікативна); як засобу впливу на рішення органів виконавчої влади, органів місцевого самоврядування та як учасника процесу їх прийняття і реалізації (інструментальна) ${ }^{4}$, .

\footnotetext{
${ }^{1}$ Авер'янов, В. Б. (ред.) (2002). Виконавча влада і адміністративне право. Київ: Ін-Юре, 220.

${ }^{2}$ Циганов, О. Г. (2016). Адміністративне оскарження як важливий засіб забезпечення законності при наданні адміністративних послуг у сфері правоохоронної діяльності. Вісник Луганського державного університету внутрішніх справ імені Е. О. Дідоренка, 1, 207-216 <http://nbuv.gov.ua/UJRN/Vlduvs_2016_1_24>. (2020, травень, 14).

${ }^{3}$ Цимбалюк, В. С., Кісілевич, К. О. (2017). Звернення громадян як важлива складова захисту прав і свобод людини і громадянина в Україні. Молодий вчений, 5.1 (45.1), 149-154.

$<$ http://molodyvcheny.in.ua/files/journal/2017/5.1/37.pdf >. (2020, травень, 14).

${ }^{4}$ Кандзюба, С. П., Кравцов, О. В. (2017). Інформаційно-аналітична система «звернення громадян» як інструмент громадського контролю. Публічне адміністрування: теорія та практика, $2<\mathrm{http}: / / \mathrm{w} . \mathrm{dbuapa.dp.ua/zbirnik/}$ 2011-02(6)/11kspigk.pdf>. (2020, травень, 14).
} 
О. Костюкевич, у свою чергу, більш широко розглядає функції права громадян на звернення та відносить до них правоохоронну функцію; функцію правореалізації; інформаційну функцію; функцію соціального контролю; функцію стимулювання діяльності державного механізму; профілактичну функцію2 .

Висновки. Грунтовний аналіз конституційно-правової сутності поняття «звернення громадян», їх видів та функціонального призначення, дозволив нам виробити авторську дефініцію «звернення людини (громадянина) у конституційно-правовому розумінні, за якою - це нормативно регламентована форма комунікативної взаємодії особи та держави, яка здійснюється шляхом подання усного або письмового (електронного) індивідуального (колективного) повідомлення до органів державної влади, місцевого самоврядування, посадових осіб цих органів та інших, уповноважених на це суб'єктів, про різноманітні питання суспільного, державного, колективного чи особистого життя, з метою налагодження діалогових форм участі в управлінні державними та суспільними справами, а також реалізації та захисту своїх прав, свобод та законних інтересів, та припускає обов'язковість їх розгляду та надання обгрунтованої відповіді у встановлені законом строки». Застосування у дефініції словосполучення «звернення людини (громадянина)» невипадкове. Адже саме така конструкція $є$ логічною з огляду на змістовне наповнення як конституційної (стаття 40 Конституції України), так і законодавчих норм, які відносять до суб'єктів подання звернень не лише громадян України, а й «осіб, які не є громадянами України і законно знаходяться на її території» (частина третя статті 1 Закону України «Про звернення громадян»).

\section{References:}

1. Busel, V. T. (ed.) (2004). Velykyy tlumachnyy slovnyk suchasnoyi ukrayinskoyi movy [Large explanatory dictionary of the modern Ukrainian language]. Kyiv-Irpin: Perun. [in Ukrainian].

2. Averyanov, V. B. (ed.) (2002). Vykonavcha vlada i administratyvne pravo [Executive power and administrative law]. Kyiv: In-Yure. [in Ukrainian].

3. Kamenska, N. (2014). Klasyfikatsiya zvernen do orhaniv publichnoyi administratsiyi za zmistom: dyskusiyni pytannya [Classification of appeals to public administration bodies by content: debatable issues]. Yurydychna Ukrayina [Legal Ukraine], 9, 10-13.<http://nbuv.gov.ua/UJRN/urykr_2014_9_4>. (2020, May, 14).

[in Ukrainian].

4. Kandzyuba, S. P., Kravtsov, O. V. (2017). Informatsiyno-analitychna systema «zvernennya hromadyan» yak instrument hromads'koho kontrolyu [Information and analytical system of "citizens' appeals" as a tool of public control]. Publichne administruvannya: teoriya ta praktyka [Public administration: theory and practice], 2 <http://w.dbuapa.dp.ua/zbirnik/2011-02(6)/11kspigk.pdf>. (2020, May, 14). [in Ukrainian].

5. Kysil, L. Y. (2017). Vidnosyny, shcho vynykayut za zvernennyamy hromadyan do orhaniv publichnoyi administratsiyi: deyaki aspekty administratyvno-pravovoho rehulyuvannya [Relationships that arise from citizens' appeals to public administration bodies: some aspects of administrative and legal regulation]. Chasopys Kyivskoho universytetu prava [Journal of Kyiv University of Law], 3, 109-113.

$<$ http://nbuv.gov.ua/UJRN/Chkup_2017_3_24>. (2020, May, 14). [in Ukrainian].

6. Kodeks administratyvnoho sudochynstva Ukrayiny, 2005 (Verkhovna Rada Ukrayiny) [Code of Administrative Procedure of Ukraine, 2005 (Verkhovna Rada of Ukraine)]. Ofitsiynyy sayt Verkhovnoyi Rady Ukrayiny [Official site of the Verkhovna Rada of Ukraine] <https://zakon.rada.gov.ua/laws/show/2747-15>. (2020, May, 14). [in Ukrainian].

7. Konstytutsiya Ukrayiny, 1996 (Verkhovna Rada Ukrayiny) [Constitution of Ukraine, 1996 (Verkhovna Rada of Ukraine)]. Ofitsiynyy sayt Verkhovnoyi Rady Ukrayiny [Official site of the Verkhovna Rada of Ukraine] $<$ https://zakon.rada.gov.ua/laws/show/254\%D0\%BA/96-\%D0\%B2\%D1\%80>. (2020, May, 14). [in Ukrainian].

8. Kostyukevych, O. K. (2011). Administratyvno-pravove rehulyuvannya realizatsiyi prava hromadyan na zvernennya: avtoreferat dysertatsiyi na zdobuttya naukovoho stupenya kandydata yurydychnykh nauk [Administrative and legal regulation of realization of the right of citizens to the address: the author's abstract of the dissertation on competition of a scientific degree of the candidate of legal sciences]. Kyiv: Interregional Academy of Personnel Management. [in Ukrainian].

\footnotetext{
${ }^{1}$ Соболь, В. А. (2014). Звернення громадян як механізм взаємодії держави та суспільства: автореферат дисертації на здобуття наукового ступеня кандидата наук з державного управління. Київ: Національна академія державного управління при Президентові України, 5-7.

${ }^{2}$ Костюкевич, О. К. (2011). Адміністративно-правове регулювання реалізації права громадян на звернення: автореферат дисертаиії на здобуття наукового ступеня кандидата юридичних наук. Київ: Міжрегіональна академія управління персоналом, 13.
} 
9. Kotlyarevska, H. M. (2010). Metodychni pytannya klasyfikatsiyi zvernen hromadyan do orhaniv vlady [Methodological issues of classification of citizens' appeals to the authorities]. Yurydychna Ukrayina [Legal Ukraine], 5, 34-39. [in Ukrainian].

10. Kravtsov, M. O. (2020). Zvernennya hromadyan yak mekhanizm publichnoho dialohu orhaniv derzhavnoyi vlady ta suspilstva [Citizens' appeal as a mechanism of public dialogue between public authorities and society]. Derzhavno-upravlinski studiyi [Public administration studies] <http://studio.ipk.edu.ua/wp-content/uploads/2020/ 04/Kravtsov_stattia-DUS.pdf $>$. (2020, May, 14). [in Ukrainian].

11. Luchenko, D. V. (2014). Skarha yak protsesualna forma pravozakhystu v administratyvno-pravovykh vidnosynakh [Complaint as a procedural form of human rights protection in administrative and legal relations]. Visnyk Natsionalnoho universytetu «Yurydychna akademiya Ukrayiny imeni Yaroslava Mudroho». Ekonomichna teoriya ta pravo [Bulletin of the National University "Yaroslav the Wise Law Academy of Ukraine". Economic theory and law], 1, 285-294. <http://nbuv.gov.ua/UJRN/Vnyua_etp_2014_1_32>. (2020, May, 14). [in Ukrainian].

12. Malkov, V. V. (1967). Sovetskoye zakonodatelstvo o zhalobakh $\bar{i}$ zayavlenikh [Soviet legislation on complaints and complaints]. Moscow: Moscow State University. [in Russian].

13. Novikov, V. D., Mytsak, B. N. (2011). Do pytannya zakhystu prav ta zakonnykh interesiv hromadyan [On the issue of protection of the rights and legitimate interests of citizens]. Naukovi zapysky Lvivskoho universytetu biznesu ta prava [Scientific notes of Lviv University of Business and Law] $<$ http://irbis-nbuv.gov.ua/ Nzlubp_2011_6_37.pdf >. (2020, May, 14). [in Ukrainian].

14. Novoselov, V. I. (1976). Pravovoye polozheniye grazhdan v sovetskom gosudarstvennom upravlenii [The legal status of citizens in Soviet public administration]. Saratov: SSU. [in Russian].

15. Ministerstvo yustytsiyi Ukrayiny (2020) [Ministry of Justice of Ukraine (2020)]. Pravo na dostup do informatsiyi yak element pravovoho statusu osoby [The right to access information as an element of a person's legal status] $<$ https://minjust.gov.ua/m/str_40016>. (2020, May, 14). [in Ukrainian].

16. Povoroznyu, M. I. (2017). Administratyvnyy pozov u systemi zasobiv zakhystu prav hromadyanyna u sferi publichno-pravovykh vidnosyn [Administrative lawsuit in the system of means of protection of civil rights in the field of public law relations]. Chasopys Kyivskoho universytetu prava [Journal of Kyiv University of Law], 3, 137-145. <http://nbuv.gov.ua/UJRN/Chkup_2017_3_31>. (2020, May, 14). [in Ukrainian].

17. Zakon pro dostup do publichnoyi informatsiyi, 2011 (Verkhovna Rada Ukrayiny). [Law on Access to Public Information, 2011 (Verkhovna Rada of Ukraine)] Ofitsiynyy sayt Verkhovnoyi Rady Ukrayiny [Official site of the Verkhovna Rada of Ukraine] <https://zakon.rada.gov.ua/laws/show/2939-17>. (2020, May, 14). [in Ukrainian].

18. Zakon pro zvernennya hromadyan, 1996 (Verkhovna Rada Ukrayiny) [Law on Citizens’ Appeals, 1996 (Verkhovna Rada of Ukraine)]. Ofitsiynyy sayt Verkhovnoyi Rady Ukrayiny [Official site of the Verkhovna Rada of Ukraine] <https://zakon.rada.gov.ua/laws/show/393/96-\%D0\%B2\%D1\%80>. (2020, May, 14). [in Ukrainian].

19. Remnev, V. I. (1964). Pravo zhaloby v SRSR [The right of complaint to the SRAC]. Moscow: Legal literature. [in Russian].

20. Sobol, V. A. (2014). Zvernennya hromadyan yak mekhanizm vzayemodiyi derzhavy ta suspilstva: avtoreferat dysertatsiyi na zdobuttya naukovoho stupenya kandydata nauk z derzhavnoho upravlinnya [Citizens' appeal as a mechanism of interaction between the state and society: dissertation abstract for the degree of Candidate of Sciences in Public Administration]. Kyiv: National Academy of Public Administration under the President of Ukraine. [in Ukrainian].

21. Tsyhanov, O. H. (2016). Administratyvne oskarzhennya yak vazhlyvyy zasib zabezpechennya zakonnosti pry nadanni administratyvnykh posluh u sferi pravookhoronnoyi diyalnosti [Administrative appeal as an important means of ensuring legality in the provision of administrative services in the field of law enforcement]. Visnyk Luhanskoho derzhavnoho universytetu vnutrishnikh sprav imeni E. O. Didorenka [Bulletin of Luhansk State University of Internal Affairs named after EA Didorenko], 1, 207-216 $<$ http://nbuv.gov.ua/UJRN/Vlduvs_2016_1_24>.(2020, May, 14). [in Ukrainian].

22. Tsymbalyuk, V. S., Kisilevych, K. O. (2017). Zvernennya hromadyan yak vazhlyva skladova zakhystu prav i svobod lyudyny i hromadyanyna v Ukrayini [Citizens' appeals as an important component of protection of human and civil rights and freedoms in Ukraine]. Molodyy vchenyy [A young scientist], 5.1 (45.1), 149-154. $<$ http://molodyvcheny.in.ua/files/journal/2017/5.1/37.pdf $>$. (2020, May, 14). [in Ukrainian].

23. Chub, O. O. (2005). Konstytutsiyne pravo hromadyan na uchast $v$ upravlinni derzhavnymy spravamy [The constitutional right of citizens to participate in the management of state affairs]. Kharkiv: Odisey

24. Shapiro, V. S. (2012). Osoblyvosti pravovoho rehulyuvannya prava hromadyanyna Ukrayiny na zvernennya [Features of legal regulation of the right of a citizen of Ukraine to appeal]. Forum prava [Law Forum], 4, $1034-1043$. $<$ http://nbuv.gov.ua/UJRN/FP_index.htm_2012_4_173>.(2020, May, 14). [in Ukrainian]. 